\title{
The Leadership Role of the Principal as Supervisor in Conflict Management at Muhammadiyah 2 Madiun High School, East Java, Indonesia
}

\author{
*Nurfaza Aula ${ }^{1}$, Afiful Ikhwan ${ }^{2}$, Nuraini $^{3}$ \\ ${ }^{1,2,3}$ Universitas Muhammadiyah Ponorogo, Jl. Budi Utomo No.10, Ronowijayan, Siman, \\ Ponorogo, East Java, Indonesia \\ *nurfazaabc@gmail.com
}

\begin{abstract}
The purpose of this study was to find out how the role and implications of the principal in carrying out his role as a leader, supervisor and administrator in combating conflict in educational institutions. This type of research is a qualitative descriptive study. The results of this research which is focused on SMA Muhamadiyah 2 Madiun are that as leaders, supervisors, and administrators have been going well. As for the supporting factors for the principal in carrying out his role, namely teachers, students, programs or plans, and curriculum, the inhibiting factors are discomfort in making decisions, facilities and infrastructure, teachers who do not have maximum scientific discipline, funding standards are still minimal, and the number of students who little influence on the financing standards of operational assistance funds received. Conflict resolution is carried out by the principal by means of deliberation and taking the middle way, advising, strengthening ties of friendship, compromising everything with various parties.
\end{abstract}

Tujuan penelitian ini adalah untuk mengetahui bagaimana peran dan implikasi kepala sekolah dalam menjalankan perannya sebagai pemimpin, pengawas dan administrator dalam penanggulangan konflik di lembaga pendidikan. Jenis penelitian ini adalah penelitian deskriptif kualitatif. Hasil penelitian yang difokuskan pada SMA Muhamadiyah 2 Madiun adalah sebagai pimpinan, pengawas, dan pengurus sudah berjalan dengan baik. Adapun faktor pendukung kepala sekolah dalam menjalankan perannya yaitu guru, siswa, program atau rencana, dan kurikulum, faktor penghambatnya adalah ketidaknyamanan dalam pengambilan keputusan, sarana dan prasarana, guru yang kurang disiplin ilmu, standar pendanaan. yang masih minim, dan jumlah mahasiswa yang sedikit berpengaruh terhadap standar pembiayaan dana bantuan operasional yang diterima. Penyelesaian konflik dilakukan oleh prinsipal dengan cara musyawarah dan jalan tengah, menasihati, mempererat tali silaturahmi, mengkompromikan segala hal dengan berbagai pihak.

Keywords: The roles of principal, leader, supervisor, administrator, conflict management.

Received: March 22, 2020; Revised: May 5, 2020; Accepted: May 30, 2020 


\section{INTRODUCTION}

The principal is a very important educational leader because the principal is directly related to the implementation of educational programs. the achievement of educational goals depends on the leadership skills and wisdom of the principal. The principal is a teacher who gets additional duties as the principal of the school(Danim, 2002). According to the regulation of the minister of national education of the Republic of Indonesia number 162 / U / 2003 regarding guidelines for assigning teachers as principals to lead and manage education in schools in an effort to improve the quality of education(Kemendikbud, 2007).

The principal as the top leader has the authority and power, as well as the competence to organize and develop his subordinates professionally. Thus the principal must have professional competence, namely: the principal as a leader, as a manager, as an educator, as an administrator, as an entrepreneur, as a work climate creator, and as a supervisor (Tim Penulis Kemendikbud, 2007).

The success of an educational institution is highly dependent on the leadership of the principal, because he is a leader who is fully responsible for his institution, he must take the institution towards the achievement of the goals that have been set, he must be able to see changes and be able to see changes and be able to see the future in a better global life (visionary) (Ikhwan, 2018b). The school principal must be responsible for the smoothness and success of all school management and management matters formally to his superiors or informally to the community who has entrusted their students. The principal as an educator, administrator, leader, and supervisor, is expected by itself to be able to manage educational institutions towards better development and can promise the future (Supriyanto, 2008).

The high school period is indeed a very decisive period in human development. A period where trial and error is still its own reasonableness, a period that is still vigorous, has not been burdened with many things, including burdened with complicated thoughts about life (Nurhayati Dewa Ayu, 2015). This period in psychology is called the adolescence period. That reason is also what makes sure the writer takes focus at the Muhammadiyah 2 Upper Middle School Madiun, East Java, Indonesia..

Conflicts can occur anywhere, including in educational institutions. Conflicts in educational institutions arise due to issues relating to leadership, management, differences in views, interests and others. Election of school principals, chancellors or other positions that are considered unfair and transparent often results in conflicts. Likewise, inopen financial management and unfair recruitment of personnel, it is usually easy to create prolonged conflicts. Some people say that conflict actually benefits institutions. Because, with the occurrence of conflict there will be internal organizational dynamics. Conflict will force the leadership group as well as members to carry out their functions and roles in an open, democratic and respectful manner among members of their community. Conflict will prevent policies that are unilateral in nature and authoritarian attitudes. However, according to the opinion of an expert in the field of organization, a conflict that exceeds its level will actually disturb the dynamics of the organization itself. The problem is how the organization is able to create conflict that is productive and not counterproductive. 
Research related to the leadership of the Principal of Bustanul Arifin which examines the effect of the leadership style of the principal on teacher achievement in junior high schools, the results of the study found that the leadership style of the principal with 4 latent variable constructs has an effect on teacher achievement in junior high schools. (Nurhayati Bustanul Arifin, 2006). Siti Zuhriah examines the effect of teacher teaching experience and principal leadership on learning performance, the result is that teacher teaching experience and principal leadership have an effect on performance (Zuhriyah, 2014). Muslimah Hikmah Wening's research on Principal Leadership Strategies in Facing the Digital Era 4.0 resulted in the principal's strategy of improving the quality of human resources in the field of Information and Communication Technology (ICT) both in terms of facilities and infrastructure, openness to developments in facing things that will happen in digital era 4.0, namely critical thinking, creativity, communication, collaboration.

Organizations that are experiencing conflict show the following characteristics: (1) there is conflict between individuals or groups, (2) there is conflict in achieving goals, (3) there is a conflict of norms, and individual and group values, (4) there is attitudes and behavior negate each other, prevent other parties, and (5) there is debate and conflict as a result of the emergence of creativity, initiative, or new ideas in achieving organizational goals (Ikhwan, 2017). Five types of conflict, namely: data conflict, conflict of interest, relational conflict, structural conflict and value-based conflict (Ikhwan, 2018a). Five styles for handling conflict: competitive style, avoidance style, compromise style, accommodating style, and collaborative style. In dealing with conflict, it is necessary to review the available interventions, and first determine what type of conflict is being faced. Data conflicts, conflicts of interest and relational conflicts are easily resolved, while structural conflicts and conflicts of value are resolved by making changes to the views held by the people concerned(Sutikno, 2018).

Of the several studies that have been carried out above, no one has discussed the inheritance of supervisors and administrators, and their implications. Thus, to find out the leadership role of the principal and its implications as a research supervisor and administrator, discuss it in this manuscript.

\section{LITERATURE REVIEW}

\section{Definition of the Role of the Principal}

The definition of a principal is a combination of the words "head" and "school". the word "head" is defined as the chairman or leader in an organization, while the school is an institution where it is a place to receive and give lessons (Mohamady, 2018).

Thus the principal is someone who is given the task of leading an educational institution in which a teaching and learning process is held between teachers and students. The principal is a person who is in control in running the wheel of leadership in an institution, the progress and retreat of an institution lies in the policy of the school principal he leads.

Role means an obligation that must be carried out by a person in accordance with the individual's position. According to J. Dwi Narwoko and Bagong Suryanto, role is a dynamic aspect of position. This means that someone has carried out the rights and obligations in accordance with his position, then that person has played a role. The 
role in it covers 3 things, namely: (a) The role includes norms associated with one's position or place in society. (b) Role as a concept of what individuals can do in society. (c) The role can be said to be an important behavior for the social structure of society (Astuty, 2017).

\section{Principal as Leader}

Leadership is one of the most important factors in an organization because most of the success and failure of an organization is determined by the leadership in the organization. As for what is meant by leadership is the ability to convince and move other people to want to work together under his leadership as a team to achieve certain goals (Setyanto, Ikhwan, Amin, Muhammad Shabir, \& Suharto, 2019). Meanwhile, Idra Fachrudi defines leadership as a group in such a way as to achieve that goal. Then according to Ukas leadership is the ability that a person has to be able to influence others, so that he wants to do something that can help achieve a goal and a goal (Harapan, 2016).

Based on these definitions, it can be concluded that leadership is a person's ability to influence others to work together so that they are willing to take actions and deeds in achieving the common goals that have been set.

In Islamic teachings the meaning of leadership is explained in the Koran surah AnNahl verse 36 which translates "And indeed, We have sent an Apostle for every ummah (to call), worship Allah and stay away from tagut, then among them there are those who are given guidance. by Allah and some remain in error. So walk on earth and pay attention to how the end of those who deny" (Rasul - Rasul) (RI, 2011).

Thus the translation of the al-quran above explains that in essence the messengers were sent to the face of the earth only to lead the people and bring them out of the darkness into bright light. No human being exists except Allah sent the Apostles to rectify the deviation of the individual faith of the people.

One of the important variables a school principal must have in carrying out his leadership wheel is the ability as a leader. As a leader, the principal must empower all the potential and existing resources in the school related to various learning programs, evaluation processes, curriculum development, management of education personnel, infrastructure, services to students, relationships with the community, to the creation of a conducive school climate (Pujianto, 2015).

As a school unit leader, the principal is required to have sufficient insight into leadership knowledge, especially in developing the school as an institution that is competent in completing students as an output that is considered quality (Kurnianingsih, 2017).

Leadership style is the attitude, gesture, or appearance that the leader chooses in carrying out his leadership duties. The styles used by a leader differ from one another, depending on the situation and condition of the leadership. Leadership style is a behavior norm that a person uses when that person tries to influence the behavior of others. According to Karwati and Priansa, leadership style is a consistent pattern of behavior aimed at by the leader and known to other parties when the leader tries to influence the activities of others (Kasidah, Murniati, 2017). Principal Leadership Style: 
First, Authoritarian Leadership Style, authoritarian comes from the word autos, which means alone and kratos which means power or strength, this leadership style is identical to a dictator, that leading is nothing but showing and giving orders so that there is an impression that subordinates or members are only follow and run it, must not argue and make suggestions.

Second, the Pseudo - Democratic Leadership Style. The term pseudo means false. So pseudo democratic means not or undemocratic. This leadership style is actually autocratic, but in its leadership it gives a democratic impression. He gave the right and power to teachers to determine and decide something, but in fact he worked by calculation. He arranged a strategy so that his wishes would come true.

Third, Free Leadership Style (Laissez Faire). This free leadership style or laissez faire is defined as letting people do what they want. This leadership style, the leader practically does not lead. A leader like this does not provide control and correction at all to the work of his subordinates or members.

Democratic Leadership Style. This democratic leadership style is the most ideal leadership style. Democratic leaders are leaders who are cooperative and not acted upon. He always stimulates his group members and always takes into account the abilities and abilities of his group (Djunaidi, 2017b).

The functions of educational leadership can basically be divided into two, namely: (1) Functions related to the goals to be achieved. Included in this group are (a) The leader functions to think and formulate carefully the group's goals and explain so that members can work together to achieve these goals. (b) The function of the leader gives encouragement to group members to analyze the situation so that a plan of leadership activities can be formulated that can give good hope. (c) The leader functions to assist group members in providing necessary information so that they can make sound considerations. (d) The leader functions to use the opportunities and special interests of group members. (2) Functions related to a healthy and pleasant working atmosphere. Included in this group are (a) The leader functions to cultivate and maintain togetherness in the group. (b) The function of the leader is to strive for a pleasant workplace, so that joy and enthusiasm for work can be fostered in carrying out the task. (c) Leaders can instill and cultivate the feeling of members that they belong to the group and are part of the group (Susanto, 2015).

\section{Principal as Supervisor}

Mulyasa explained that supervision is a process specifically designed to help teachers and supervisors learn daily tasks at school so they can use their knowledge and abilities to provide good service to parents of students and schools (Juliantoro, 2017).

One of the duties of the principal is as a supervisor, which is to supervise the work performed by educational personnel. Supervision can actually be carried out by the principal who acts as a supervisor, but in a modern educational organizational system, special supervision is treated that is more independent, and can increase objectivity in coaching and carrying out its duties (Febriyanti, 2017).

The principal in his position as a supervisor is obliged to guide teachers to become good educators and teachers. For teachers who are already good, their quality can be maintained and vice versa for teachers who are not good, their quality can be developed for the better. In addition, both competent and weak teachers must be 
endeavored so as not to be outdated in the learning process and the material being taught (Pidarta, 2011).

As explained in Permendiknas No.13 of 2007, that the principal as a supervisor must be able to have competencies including: Planning an academic supervision program in order to increase teacher professionalism, carrying out academic supervision of teachers using appropriate supervision approaches and techniques, following up on the results of academic supervision of teachers in order to increase teacher professionalism (Arif, 2016).

Things that need to be considered and developed in each teacher by the principal as a supervisor are (1) teacher personality, (2) continuous professional improvement, (3) learning process, (4) mastery of subject matter, (5) diversity of abilities teachers, (6) regional diversity, and (7) the ability of teachers to work with the community (Pidarta, 2011). Meanwhile, according to Ngalim Purwanto, the duties of the principal as a supervisor are: (a) Generating and stimulating teachers and school employees in carrying out their respective duties as well as possible. (B) Together with the teachers trying to develop, find, and using teaching methods that are more in line with the demands of the current curriculum. (c) Fostering good, harmonious cooperation between teachers and other school employees. (d) Trying to improve the quality and knowledge of teachers and school staff, including holding group discussions, providing a school library, and sending them to attend courses, seminars according to their respective fields. (e) Fostering cooperative relationships between schools and BP3 and other agencies in order to improve the quality of education for students (Purwanto, 2009).

From the above opinion about the role or duties of the principal as a supervisor, in substance, it aims to provide convenience and comfort to teachers and staff in overcoming problems related to planning, implementation, and assessment in order to increase teacher professionalism and also foster cooperative relationships. between teachers and other agencies in order to improve the quality of student education.

\section{Principal as Administrator}

The school principal functions as an administrator according to Mulyasa, the school principal has a very close relationship with various administrative management activities that are recording, compiling and documenting all school programs. Specifically, the principal must have the ability to manage the curriculum, manage administration of facilities and infrastructure, manage archival administration and manage financial administration (Djunaidi, 2017a).

As the principal administrator has two main duties. First, as controlling the organizational structure, which is controlling how to report, with whom the task should be done and with whom to interact in doing the task. Second, carry out substantive administration which includes curriculum administration. Student, personnel, and general administration (Mahardhani, 2015).

So a school principal as an administrator must be able to manage all the administration in the school, this is very important to do because it ensures the smooth running of the program.

\section{Conflict Management in Educational Institutions}


Conflict management is the ability to control conflict that occurs, which demands certain management skills. In Islam, conflict is not as an end but as a means to unite various opposing things to free human life from individual interests and from ugliness so that they can be led to the right path.

Conflict stems from errors in communication or distortion, organizational structure, and human factors. Other factors that become sources of conflict are differences in functions within the organization; the power clash between individuals and subsystems, the existence of different roles, and the pressure imposed from outside the organization. In addition, there are several things that have become sources of conflict, namely differences of opinion, misunderstanding, feeling disadvantaged, and too sensitive.

Conflict has many types, in general there are two types of conflict, namely functional conflict and dysfunctional conflict. In addition, conflicts can be classified into conflict of purpose, role conflict, conflict of values, and conflict of policies. If viewed based on conflicting parties, conflicts can be classified into conflicts within individuals, conflicts between individuals in the organization, conflicts between groups within the same organization, and conflicts between organizations (Muliati, 2016).

\section{METHOD}

This research is a descriptive qualitative case study type. According to the author, the determination of the research location at the Muhammadiyah 2 Madiun Middle School is very unique from other locations because it is included in the category of private schools that are of interest to the community. Data were obtained from the principal, teachers, employees, school committees, guardians of students, students, alumni, and other parties involved, with data collection techniques using in-depth interviews, observation and documentation. The analytical tool used is the qualitative analysis model of Miles and Huberman data reduction, data display and verification. Checking the validity of the data using triangulation; credibility, transferbility, dependability and confirmability. The focus of this study is the leadership role of the principal as a leader, supervisor and administrator in managing conflict and its implications for application in the research location.

\section{RESULT AND DISCUSSION}

\section{Role of Principals as Leaders, Supervisors and Administrators in Conflict Management}

According to the findings of an interview with the principal of SMA Muhamadiyah 2 Madiun, the principal as a leader has a set of duties and roles that are carried out, namely as follows: First, as an executive. He tried to fulfill the will and needs of his group. Second, as the holder of responsibility for the actions of its members which are carried out on behalf of the group. third, as a controller of internal (supervising), namely guarding against disputes. Fourth, as a planner who makes and plans school programs. Fifth, as an intermediary in resolving disputes or receiving complaints between its members. sixth, as an intermediary in resolving disputes without favoritism. 
The principal in his position as a supervisor, namely supervising the work carried out by education personnel, according to the results of interviews with the principal of SMA Muhamadiyah 2 Madiun, namely as a supervisor so that the implementation goes well the principal fosters teachers to become good educators and teachers, provides a per- teacher formation in managing the teaching and learning process, being democratic provides the opportunity for teachers to generate ideas and opinions for common goals, compiling classroom supervision programs, developing supervision programs for extra-curricular activities, developing library supervision programs, and examinations.

The principal as an education administrator is responsible for the smooth implementation of education and teaching in his school. The results of interviews with the principal of SMA Muhammadiyah 2 Madiun related to their role as administrator, namely: First, making plans or compiling school work programs. Second, organize activities and establish working relationships between personnel. Third, coordinating the work and assignments of the teacher for the stated goals. Fourth, managing staffing, division of work assignments for teachers and school employees.

\section{Implications of the Role of the Principal in Conflict Management at SMA Muhammadiyah 2 Madiun}

Based on the research findings, the obstacles to the principal's role as a leader in SMA Muhamadiyah 2 Madiun are: (1) Discomfort in dealing with disputes between one teacher and another or one employee with another employee because of the mental burden that appears to think the principal is taking sides or feels not fair, (2) Lack of complete facilities and infrastructure which makes school programming activities late and not all teachers have scientific disciplines that are in accordance with the subject being taught. (3) Financing standards are still minimal so that they have not been maximal in developing the talents of students, the standard of funding related to school operational assistance funds received is not much.

The supporting factors for the principal in carrying out his role as a leader, supervisor and administrator at SMA Muhamadiyah 2 Madiun: Teachers who are influential in the teaching and learning process, students who are the main object in the teaching and learning process, good facilities even though they are still in minimal numbers, clear objectives for achieve goals, a dynamic curriculum influenced by education that is renewed by various changes and the education that underlies.

\section{Leadership of the Principal as Supervisor in Conflict Management}

The implementation of conflict management in the leadership of the principal as a supervisor at SMA 2 Muhammadiyah Madiun is highly prioritized and even occupies a strategic position as an effort to maintain public trust and maintain the sustainability of the education process. Without a principal who is reliable in conflict management, it is very difficult to be able to maintain educational institutions, even develop well and optimally with public trust.

Conflict management at SMA 2 Muhammadiyah Madiun is a process that is carried out consciously, directed, programmed and integrated, aiming to keep educational institutions running and even improve the quality of educational institutions and be able to manage these Islamic educational institutions properly, so that educational institutions become of good quality. and excels. 
Conflict management at SMA 2 Muhammadiyah Madiun is carried out through a process of identifying the causes of conflict, conflict impacts, conflict resolution and conflict management strategies. Conflict management carried out by the head of the school, the Elementary Education Council and Muhammadiyah leaders as the person in charge of the educational institution in carrying out the implementation runs well consistently and is guided by the Basic Articles and Bylaws of the Dikdasmen Council.

After knowing the causes of the conflict, knowing where the conflict arose, or whether the source of the conflict originated, then the principal then classifies the sources of conflict, for example the work responsibility group, the facilities used in teaching and learning activities, classify conflicts that criticize issues such as payment of honoraria postponed, the principal then analyzes that the conflict is important and urgent to resolve because it has a negative impact, namely: the work atmosphere is uncomfortable, performance decreases, lack of enthusiasm, teachers arrive late and have an impact on tension between individuals so that the work atmosphere becomes tense, work is hampered which has an impact on the delay in achieving targets.

The principal also knows that conflict has a positive and functional effect. The positive impact of conflict is: being cooperative, putting institutional interests above personal interests, not prioritizing personal interests, creating awareness of organization, finding good solutions, becoming wiser in making policies.

After the principal knows the impact of the conflict, then analyzes understanding the position of the conflict and determines the solution to be taken. The principal understands that each different character will trigger conflict, however, as long as it is still in a reasonable stage, and maybe there must be conflict first in order to find a good solution and in order to make policies with existing differences, the impact of conflict is like this which are functional.

The positive impact of conflict is: being cooperative, putting institutional interests above personal interests, not prioritizing personal interests, creating awareness of organizations, finding good solutions, making wiser decisions. The negative impacts are: the work atmosphere is uncomfortable, performance decreases, lack of enthusiasm, teachers arrive late and have an impact on tension between individuals so that the work atmosphere becomes tense, work is hampered which has an impact on delay in achieving targets.

The impact of the conflict that occurred at SMA Muhammadiyah 2 Madiun is in accordance with the results of research by Russell and Jerome in 2012, which explained that conflict has both positive and negative impacts. According to him, conflict can be positive when it encourages creativity, new looks, clarification of viewpoints, and the development of human abilities to deal with interpersonal differences. Conflict can become negative when resistance to change is created, symptoms develop in organizations or relationships, fosters distrust, builds feelings of defeat, or widens gaps of misunderstanding.

The impact of the conflict that occurred at SMA Muhammadiyah 2 Madiun is also in accordance with the results of research by Bano et al., "Conflict may be destructive if it leads to effective communication breakdown and work relationships, tension, argument, low performance of team members and hostility which in turn affects the smooth running of the schools" (Bano, H., Ashraf, S., and Zia, 2013), It can be understood that conflict can be destructive if it leads to ineffective communication 
disorders among members and working relationships, tension occurs between members, unhealthy arguments, decreased performance of team members and hostility which in turn affects the smooth running of school performance.

Furthermore, this is the same as the research results of Makaye, J., and Ndofirepi, A.P. "However, if conflicts are properly handled, benefits may accrue; contributing to solidarity within conflicting groups and reconciliation of legitimate interests where, in turn, relationships are strengthened, there is enhanced identification of problems and solutions, increased knowledge or skill, and peace is safeguarded" (Makaye, J., and Ndofirepi, 2012). Likewise with the research results of Bano, Ramani \& Zhimin, "Ability to manage or resolve conflicts is therefore important for school leaders for smooth running of the school" (Ramani K and Zhimin, 2010).

Thus, if the conflict is handled properly, it will add to the benefits; contributing to solidarity within warring groups and reconciliation of legitimate interests where, in turn, relationships are stronger, there is increased identification of problems and solutions, increased knowledge and skills, and peace is maintained. Therefore, the ability to manage or resolve conflicts is important for school leaders for the smooth running of the school.

\section{Conflict Resolution at SMA Muhammadiyah 2 Madiun}

The conflict resolution is carried out by the principal as a supervisor by taking the best steps to manage conflict, namely by building good communication with subordinates and being able to learn things related to the nature of each individual. Because the nature of each individual is different, apart from that when there is a conflict resolution, which is usually done by using a familial approach, the principal even visits the home of both teachers and then communicates the problems that are happening, to get the best middle way.

The solution applied is communication and coordinated to communicate matters in making policies. by bringing together two different opinions to get a mutual agreement and can be implemented together with full responsibility.

Conflict resolution is carried out by the principal by developing spiritual values guided by the Qur'an and Hadith and heeding the Articles of Association and or Bylaws (AD/ART) of the Muhammadiyah Dikdasmen Council.

The results of this study are in line with what is contained in al-Qur'an surah Asy Shura verse 38 which states that problems between humans are solved by deliberation. Although not all things can be resolved by deliberation. Allah SWT also says to reconcile all conflicting parties in the event of a conflict as in Al-Qur'an surah $\mathrm{Al}$ Hujurat verse 9. Similar steps should also be applied in all organizations so that the middle way of conflict can be achieved.

In contrast to the research results of Birhanu Shanka, Mary Thuo who explained that "Conflict resolutions used in schools include; building on leadership skills and having a mechanism in place to deal with conflicts. They also work on being knowledgeable about sources of conflicts, expanding resources, giving staff opportunities for growth, and also trying to embrace change. Further, leaders strive to build on leadership skills like knowing when to switch leadership styles based on situation, being accountable and responsible, they try to involve teachers in decision making, and create ways to recognize and reward staff, they try to understand individual uniqueness, and ensure the school environment is safe for learning (Birhanu Shanka, 2017). 
The results of these studies explain that the conflict resolution used in schools includes; build leadership skills and have mechanisms for dealing with conflict. They also seek to have knowledge of sources of conflict, expand resources, provide opportunities for staff to develop, and also try to embrace change. Furthermore, leaders seek to build leadership skills such as knowing when to change leadership style based on situation, and being responsible, principals engage teachers in decision making, and create ways to recognize and reward staff, principals understand individual uniqueness, and ensure the school environment is safe for learning.

The main conflict resolution implemented includes; build leadership skills, follow rules and regulations. embrace change, allocate resources wisely, be involved in decision making, provide opportunities for training, and understand individual differences and roles.

\section{Conflict Management Strategies in Islamic Perspective}

Leadership is an important strength in the framework of management, therefore the ability to lead effectively is the key to becoming an effective manager. The essence of leadership is followership, the willingness of others or subordinates to follow the leader's wishes, that is what causes a person to become a leader. In other words, a leader will not be formed if there are no subordinates.

A school leader (leadership) should create a safe and peaceful atmosphere in the school environment. This is of course the responsibility of a school principal as a leader. Related to this, the principal is required to have strategies that can resolve conflicts that occur.

The conflict management strategy used at SMA Muhammadiyah 2 Madiun is that the principal approaches conflicting parties in conflict situations and determines conflict management strategies, namely collaboration, compromise and accommodation. The use of collaborative conflict management strategies, compromise and accommodation depends on exploring the nature of conflicts that occur in schools and the various causes. The school principal makes compromises to both parties in dispute, until both parties agree to give in to each other and accept the decision together. In the sense of the word there is no win or loss in solving the problems that occur. But if the problem is more serious, the solution involves the foundation with accommodating solutions. Based on the findings in the field, the conflict management strategy implemented at SMA Muhammadiyah 2 Madiun uses collaboration, compromise and accommodation.

It can be understood that conflicts that are caused due to high levels of interdependence, individual differences, differences in goals and roles, conflicts tend to arise between school members and school principals tend to resolve these conflicts using integrating strategies, dominate in resolving conflicts.

Tabayun is an act of clarifying information that reaches the leader in an organization. When receiving information, it is better to examine who brought the news, and where and who is the source of the news because the news is not clear, especially if it is only an issue that will be prone to causing slander and fighting. If the organization is managed with issues and rumors, the personnel in the organization will not feel comfortable in carrying out their activities, maybe even lazy because of the unclear instructions and division of tasks that must be done. Allah says, "O you who believe, if a wicked person comes to you with news, then check carefully so that you do not 
impose a disaster on a people without knowing the circumstances that cause you to be sorry for your actions" (Indonesia, 2012).

The discussion here is that the analysis researcher uses domain and taxonomic analysis. Domain analysis is generally carried out to obtain a general and comprehensive picture of the social situation under study or the object of research. Conflict Management at SMA Muhammadiyah 2 Madiun, based on research findings indicate that the identification of the causes of conflict in Muhammadiyah educational institutions is carried out by the principal, involving teachers and other stakeholders by developing spiritual values.

The process of identifying the causes of conflict in Muhammadiyah educational institutions is carried out by the principal systematically referring to the vision and mission of the Muhammadiyah educational institution he leads, so that the goal of solving the problems the institution wants to achieve can be clearly identified and arranged in the form of work programs, both short-term work programs. , medium and long term work programs. This is in accordance with the theory of Hardjana, A.M. which explains that conflict management is useful in achieving the goals fought for and in maintaining good relations between the parties to the conflict. Conflict management also aims to build and maintain cooperative relationships with subordinates, peers, superiors and outsiders (Hardjana, 1994).

In identifying the causes of the conflict, the principal involved all related parties such as Waka, teachers, TU, school committee and practitioners, and stakeholders. The involvement of stakeholders is very important in the conflict management planning process in order to make schools that are accountable, superior and highly competitive.

Symptoms of conflict appear in educational institutions as a result of teachers who are in conflict, conflicting relationships between teachers, in other words that the relationship that occurs between one teacher and another teacher is not good or there is no harmony in interaction. Furthermore, to find out the symptoms of conflict, the principal makes direct observations at school, with the meaning of the word that in order to detect the symptoms of conflict, complete observations are made from the start of the teachers coming to school, preparation for class, the learning process, rest conditions to the teachers and staff. home education. Observations sometimes take several days.

The principal identifies the causes of conflict by calling the deputy principal, teachers, education staff in order to establish good communication with subordinates, the principal calls the relevant parties to get sufficient information, after coordinating well then determines when to negotiate, who is participate in the negotiations, when will the deliberations be held, when to make a report to the leadership.

The principal then identifies the symptoms of conflict, this is done carefully and clearly, such as there have been differences of opinion, job dependence, differences in status and roles, miscommunication, misunderstandings, overlapping division of tasks, late payment, too sensitive.

In determining conflict resolution, the principal uses an approach by advising teachers who are involved in conflict, communicating the problems at hand, and building teacher confidence that every problem must have a solution. This can promote a positive school climate. The findings in the field are in accordance with the message of Shaykh Ibn Uthaimin rahimahullah said which means "Among the obligations of a 
Muslim to another Muslim is that you have to advise him if he asks you for advice, so that you will show him what you like for yourself, because someone who cheating is not one of us. If he consults you (asks for advice) when dealing with someone or in matters of his marriage or other matters, then if you know the goodness of him then direct him to him. If you know bad from him then warn him from him. If you don't know about him then tell him; I don't know about him. If he asks you to explain a matter that he should stay away from him then explain it to him " (Utsaimin, n.d.).

\section{CONCLUSION}

The role of the principal at SMA Muhamadiyah 2 Madiun is First, as an executive. Second, as the holder of responsibility for the actions of its members which are carried out on behalf of the group. third, as a controler of internal (supervising) Fifth, as an intermediary in resolving disputes or receiving complaints between members. The role of the principal as a supervisor at SMA Muhamadiyah 2 Madiun is to guide teachers to become good educators and teachers, to provide teacher performance assessments in managing the teaching and learning process and being democratic. The role of the principal as an administrator at SMA Muhamadiyah 2 Madiun is First, making plans or compiling school work programs. Second, organize activities and establish working relationships between personnel. Third, coordinating the work and assignments of the teacher for the stated goals. Fourth, managing staffing, division of work assignments for teachers and school employees.

The supporting factors for the role of the principal in SMA Muhamadiyah are teachers, students, facilities, plans and curriculum, while the inhibiting factors are inconvenience in making decisions, minimal facilities and infrastructure, not all teachers have scientific disciplines, low standard of financing, and receipt of funds. not great surgical assistance.

The causes of conflict at SMA Muhammadiyah 2 Madiun are (a) differences in opinion, job dependence, differences in status and roles, eg communication, division of tasks, delay in honoraria, differences in interests, financial management, student management, misunderstanding, too sensitive, job responsibilities. , and the learning facilities used; (b) the resulting conflict impacts are functional, such as being cooperative, prioritizing institutional interests, creating organizational awareness, finding the best solution, making decisions wiser. Dysfunctional, such as an uncomfortable work atmosphere, decreased performance, lack of enthusiasm, arriving late home early, the work atmosphere becomes tense, work is hampered, and delays in achieving targets; (c) conflict resolution is carried out by the principal by means of deliberation and taking the middle path, advising, strengthening ties of friendship, compromising both parties, accepting joint decisions based on spiritual values and heeding the AD / ART of the Muhammadiyah Dikdasmen Council.

\section{REFERENCES}

[1] Arif, S. (2016). Peran kepala Sekolah Sebagai Supervisor.

[2] Astuty. (2017). Peran Kepemimpinan Kepala Sekolah Dalam Mengembangkan Kompetensi Guru Di SMK Negeri 2 Kabupaten Penajam Paser Utara. Administrasi Publik, 5(1), 53-91. 
[3] Bano, H., Ashraf, S., and Zia, S. (2013). Conflict: factors and resolution strategies adopted by administrators of schools for visually impaired students. Mediterranean Journal of Social Sciences, 4(4), 405-408.

[4] Birhanu Shanka, M. T. (2017). Conflict Management and Resolution Strategies between Teachers and School Leaders in Primary Schools of Wolaita Zone, Ethiopia. Journal of Education and Practise, 8(4).

[5] Danim, S. (2002). Inovasi Pendidikan Dalam Upaya Peningkatan Profesionalisme Tenaga Kependidikan. Bandung: CV.Pustaka Setia.

[6] Djunaidi. (2017a). Kepemimpinan Kepala Sekolah dalam Meningkatkan Kinerja Guru. Tarbiyatuna, 2, 103.

[7] Djunaidi. (2017b). Kepemimpinan Kepala Sekolah Dalam Meningkatkan Kinerja Guru. Tarbiyatuna, 2(1), 106-108.

[8] Febriyanti. (2017). Peran Kepala Sekolah Sebagai Supervisor Dalam Meningkatkan Kualitas Pembelajaran di Ma Patra Mandiri Plaju Palembang. Islamic Education Manajement, 3, 60.

[9] Harapan, E. (2016). Visi Kepala Sekolah Sebagai Penggerak Mutu Pendidikan. Manajemen Kepemimpinan Dan Supervisi Pendidikan, 1, 137.

[10] Hardjana, A. M. (1994). Konflik di Tempat Kerja. Yogyakarta: Kanisius.

[11] Himpunan Peraturan Menteri Pendidikan Nasional Tahun 2003,cet 2. (2007). Jakarta: Sinar Grafika.

[12] Ikhwan, A. (2017). Development Of Quality Management Islamic Education In Islamic Boarding School (Case Study Madrasah Aliyah Ash Sholihin). Al-Hayat: Journal of Islamic Education (Vol. 1).

[13] Ikhwan, A. (2018a). Sistem Kepemimpinan Islami: Instrumen Inti Pengambil Keputusan pada Lembaga Pendidikan Islam (Vol. 3). Juli-Desember.

[14] Ikhwan, A. (2018b). Sistem Kepemimpinan Islami Instrumen Inti Pengambil Keputusan pada Lembaga Pendidikan Islam. Istawa: Jurnal Pendidikan Islam, 3(2), 111-154. https://doi.org/10.24269/ijpi.v3i2.1503

[15] Indonesia, C. I. (2012). Al-Qur'an Cordoba. Bandung: Bandung.

[16] Juliantoro, M. (2017). Peran Kepala Sekolah dalam Meningkatkan Mutu Pendidikan. Al Hikmah, 5, 37.

[17] Kasidah, Murniati, B. (2017). Kepemimpinan Kepala Sekolah Dalam Meningkatkan Kinerja Guru Pada Sekolah dasar Luar Biasa Negeri Banda Aceh. Administrasi Pendidikan, 3, 128.

[18] Kurnianingsih. (2017). Peran Kepala Sekolah dalam Meningkatkan Kompetensi Guru. Management and Administration Review, 1.

[19] Mahardhani, A. januar. (2015). Kepemimpian Ideal Kepala Sekolah. Dimensi Pendidikan Dan Pembelajaran, 3, 2.

[20] Makaye, J., and Ndofirepi, A. P. (2012). Conflict resolution between heads and teachers: the case of 4 schools in Masvingo Zimbabwe. Greener Journal of Educational Research, 2(4), 105-110. 
[21] Mohamady, Z. A. (2018). Peran Kepala Sekolah Dalam Mengembangkan Mutu Budaya Organisasi. Muslim Heritage, 1, 410-411.

[22] Muliati, I. (2016). Manajemen Konflik dalam Pendidikan Menurut Perspektif Islam. Jurnal Tingkap, 12(1), 39-52.

[23] Nurhayati Dewa Ayu, E. E. (2015). KONSELING SINGKAT BERFOKUS SOLUSI UNTUK MENINGKATKAN ORIENTASI MASA DEPAN PADA BIDANG PENDIDIKAN. HUMANITAS: Indonesian Psychological Journal, (Vol 12, No 1: Vol 12 No 1 Feb 2015), 1-11. Retrieved from http://journal.uad.ac.id/index.php/HUMANITAS/article/view/3822

[24] Nurhayati Bustanul Arifin, S. N. (2006). PENGARUH GAYA KEPEMIMPINAN KEPALA SEKOLAH TERHADAP KINERJA GURU. Ilmu Pendidikan: Jurnal Kajian Teori Dan Praktik Kependidikan, 1(Vol 33, No 1 (2006)), 13. Retrieved from http://journal.um.ac.id/index.php/ilmupendidikan/article/view/1188

[25] Pidarta, M. (2011). Manajemen Pendidikan Indonesia. Jakarta: Rineka Cipta.

[26] Pujianto. (2015). Fungsi Kepala Sekolah Dalam Membina Kompetensi Pedagogik Guru. Manajer Pendidikan, 9, 766.

[27] Purwanto, M. N. (2009). Administrasi dan Supervisi Pendidikan. Bandung: PT Remaja Rosdakarya.

[28] Ramani K and Zhimin, L. (2010). A survey on conflict resolution mechanisms in public secondary schools: A case of Nairobi province. Educational Research and Reviews, 5(5), 242-256.

[29] RI, K. A. (2011). Al-Qurana 20 Baris Terjemah. Bandung: Mikraj Khazanah Ilmu.

[30] Setyanto, E., Ikhwan, A., Amin, S., Muhammad Shabir, U., \& Suharto, S. (2019). Challenges of the change management for managing people and organizational culture. International Journal of Recent Technology and Engineering, $\quad 8(2 \quad$ Special $\quad$ Issue 11$)$. https://doi.org/10.35940/ijrte.B1503.0982S1119

[31] Standar Kompetensi Kepala Sekolah TK, SMP, SMA dan SLB. (2007). Yogyakarta: Pustaka Yustria.

[32] Supriyanto, M. dan T. (2008). Manajemen dan Kepemimpinan Pendidikan Islam. Bandung: Refika Aditama.

[33] Susanto, H. (2015). Kepala Sekolah Sebagai Pemimpin Pendidikan.

[34] Sutikno, T. A. (2018). Pendekatan Manajemen Konflik Pada Lembaga Pendidikan. Tekno, 10(2), 97.

[35] Utsaimin, S. I. (n.d.). Adh-Dhiya' al-Lami' min al-Khuthab al-Jawami (asySyamilah).

[36] Zuhriyah, S. (2014). PENGARUH PENGALAMAN MENGAJAR GURU DAN KEPEMIMPINAN KEPALA SEKOLAH TERHADAP KINERJA GURU SD KECAMATAN KASIHAN KABUPATEN BANTUL. ELEMENTARY SCHOOL (Jurnal Pendidikan Dan Pembelajaran Ke-SD-An), 2(Vol 1, (2014): 
105 Al-hayat: Journal of Islamic Education (AJIE)

e-ISSN: 2599-3046 (online) | Volume 4, Issue 1 | January - June 2020

p-ISSN: $2657-1781$ (print)

Volume 1 Nomor 2 Juli 2014). Retrieved from

https://journal.upy.ac.id/index.php/es/article/view/608 